\title{
Forum
}

\section{Should conservationists pay more attention to corruption?}

\author{
Robert J. Smith and Matthew J. Walpole
}

\begin{abstract}
Corruption is known to limit economic development and fuel poverty, but it may also hinder conservation efforts and contribute to biodiversity loss. Here we explore some of the ways that corruption may affect conservation. We argue that corruption has potentially significant implications that should be highlighted and tackled directly. Unfortunately, research into the topic lags behind that in other sectors and empirical studies are scarce and underdeveloped. The result is that, whilst some academics and practitioners cite corruption as a
\end{abstract}

threat to biodiversity and call for efforts to increase transparency and accountability, we currently know little regarding the nature and magnitude of any effects it may have. Whilst precautionary measures can be built into conservation projects to pre-empt corruption, further research would help to shed light on this issue and aid the development of appropriate responses.

Keywords Biodiversity conservation, corruption, governance, mitigation strategies.

\section{Introduction}

Corruption, which is defined as 'the unlawful use of public office for private gain' (Transparency International, 2003), is an ancient and widespread affliction and a systemic feature of many economies (Azfar et al., 2001). It manifests itself in a variety of ways, including the embezzlement of funds, the demanding of bribes for compliance, patronage or political influence, and the acceptance of bribes to overlook illegal activities (Davis, 2004). The added costs that corruption places on society, and its impact on investor and donor confidence, generally limits economic growth and productivity (Mauro, 1995; Kauffman, 1997; Campos et al., 1999; Doh et al., 2003; Lambsdorff, 2003; Rock \& Bonnett, 2004). This is particularly so in developing countries and those with weak or transitional governments (Shleifer \& Vishny, 1993; Bardhan, 1997; Rose-Ackerman, 1999; Sajo, 2003).

The detrimental impact of corruption on social and economic development is widely recognized. The World Bank (2000) has strategies to assist recipient countries tackle corruption, whilst Transparency International works to monitor and highlight the problem. Transparency International has developed the Corruption

Robert J. Smith (Corresponding author) and Matthew J. Walpole* Durrell Institute of Conservation and Ecology, University of Kent, Canterbury, Kent, CT2 7NS, UK. E-mail r.j.smith@kent.ac.uk

${ }^{*}$ Current address: Fauna \& Flora International, Great Eastern House, Tenison Road, Cambridge, CB1 2TT, UK.

Received 25 February 2004. Revision requested 1 July 2004 Accepted 3 November 2004
Perception Index, which gives a score for each country based on interviews with local and expatriate business people and country analysts (Transparency International, 2003). In 2003 this system produced an Index score for 133 countries to identify where anti-corruption measures should be focused, and Transparency International and others have developed toolkits to fight corruption (Kiltgaard, 1998; Transparency International, 2002; Gupta \& Siebert, 2004). In the same year, 95 countries signed the UN Convention against Corruption (UN, 2003), which promotes greater transparency across all sectors of government and society.

We argue here that the implications of corruption for conservation are severe but, despite the apparent upsurge in commitment to fighting corruption, the current state of knowledge and understanding regarding its impacts and the means to tackle it are underdeveloped. We believe that the topic demands greater attention by researchers and conservationists.

\section{Implications of corruption for conservation}

It has been argued that, by limiting economic growth, corruption has the potential to reduce biodiversity loss (Laurance, 2004). However, there are several reasons to believe that conservation may be adversely affected by corruption. This is because our efforts to avert the current biodiversity crisis rely on adequate financial resources (Balmford \& Whitten, 2003), law enforcement (LeaderWilliams et al., 1990) and political support (Myers, 1998; Johns, 2003), and these efforts are hampered whenever such resources are lacking. Yet these are the very things 
most susceptible to corruption because they can all be weakened by bribery and embezzlement. Moreover, corruption is most prevalent in developing countries with low government salaries, weak regulatory institutions, high political patronage and almost non-existent accountability (Kaufmann, 1997; Laurance, 2004). Yet such countries are often those with the greatest natural resources and areas of highest conservation value, suggesting that many biodiversity elements may be at risk from poor governance (Smith, Muir et al., 2003).

There are additional reasons for expecting that conservation may be particularly susceptible to issues of poor governance. Many projects are externally funded, involve low paid officials and are poorly scrutinized; these factors and the high value of many natural resources provide an opportunity and incentive for corrupt individuals to misappropriate funds and resources or benefit from illegal overexploitation with little fear of detection. Equally, natural resource management institutions are often particularly weak, especially in relation to common property resources, thereby enabling corruption to prevail (Barrett et al., 2001). Moreover, since the environment is a relatively 'soft' political issue for most governments (Smith, Obidzinski et al., 2003), it is easily overridden by other environmentally damaging sectors (including construction and resource extraction) that may be more willing and able to buy political influence. It has been shown that corruption reduces the stringency of environmental policies (Damania et al., 2003).

The impact of corruption on conservation is likely to manifest itself in two ways: (1) reduced effectiveness of conservation programmes through a reduction in available financial resources, law enforcement and political support, and (2) an incentive for the overexploitation of resources. The latter may incur not only direct loss of biodiversity through extraction, but additional environmental costs such as pollution, soil erosion and climate change. Currently, however, the extent of these impacts is unclear.

\section{The state of knowledge regarding corruption and conservation}

Corruption has received little overt scrutiny by conservationists, and where it has this has mostly been confined to resource overexploitation. Numerous case studies have suggested that corruption may be a key factor in the loss of tropical forests through unsustainable or illegal logging (Huber, 2001; Jepson et al., 2001; McCarthy, 2002). For example, in 1996 illegal logging cost Indonesia US $\$ 660$ million, or 1.5\% of its GDP (Palmer, 2001), and estimates suggest that $20-80 \%$ of all globally harvested timber may be illegally sourced (WRI, 2003).
Illegal logging generates higher incomes for corrupt officials than legal logging, which in turn provide an incentive for unsustainable use (Palmer, 2001). This can be exacerbated by a weak institutional environment that reduces the likelihood of detection and penalty, and thus the required level of bribe. For example, recent research in Indonesia revealed that illegal logging increased when the government was weakened and responsibility for issuing licences was devolved to local government (Smith, Obidzinski et al., 2003). Decentralization decreased the cost of bribing officials, as power was more evenly distributed throughout the system so that no actor could monopolize control, whilst the weaker government system was less able to control independent fiefdoms or maintain previous levels of surveillance.

Corruption also has an indirect impact on large mammal flagship species such as elephants, tigers and primates that inhabit illegally logged tropical forest (Barnes et al., 1995; Robertson \& van Schaik, 2001; Kinnaird et al., 2003), and an unknown impact on forest biodiversity as a whole. In contrast, there is much more evidence for the direct impacts of corruption on species that are commercially valuable. Where a species is traded, legally or otherwise, corruption can act at numerous places along the supply chain. It may affect how well a population is protected in the field, as well as how harvested products are moved and traded nationally and internationally. Collusion by corrupt officials in the illegal trade of rhino horn (Martin \& Vigne, 2003) and ivory (Nishihara, 2003) has been highlighted in several countries, fuelled by the high value of these items and relatively low risk of detection and penalty (LeaderWilliams \& Milner-Gulland, 1993). Moreover, as an indicator of a possible link, the rate of change of both African elephant and black rhino populations in a number of range states was more strongly correlated with corruption scores than poverty levels or human population density (Smith, Muir et al., 2003).

The extent to which money is directly embezzled from conservation budgets is largely unknown, although an estimated $30 \%$ of the World Bank's development aid budget to Indonesia in 1998, which includes environmental projects, was illegally siphoned off (Robertson \& van Schaik, 2001). There is some evidence of appropriation and monopolization of benefits in devolved, communitybased projects where poor governance remains an important concern (Wells et al., 1999; Roe et al., 2001). This is because communities in poor countries with low governance levels rarely have the power to prevent the actions of corrupt officials and elites, who prevent the transfer of real power, demand bribes, or embezzle funds generated by such projects.

In Uganda, for example, corruption was viewed as one of the four main problems ailing revenue-sharing 
programmes around protected areas (Archabald \& Naughton-Treves, 2001). Evidence of misappropriation and direct embezzlement of funds by officials was uncovered, with some planned community projects being shelved for lack of funding as a result. Revenues generated from tourism in and around the Masai Mara National Reserve in Kenya were almost entirely expropriated by local elites, with only $6.5 \%$ of that earmarked for local community projects being dispersed and the majority being diverted by various administrative mechanisms alongside some direct embezzlement (Thompson \& Homewood, 2002). This means that such projects fail to benefit the poor, who are the most disenfranchised by conservation efforts, and fail to reinvest in the conservation of the natural resources on which these people rely. These projects also receive little outside scrutiny because they are often small-scale and located in remote areas, making it difficult for outsiders to uncover and publicize problems.

\section{Addressing the problem}

Recognizing the problem is the first step to addressing it, and corruption is an issue that needs closer scrutiny. However, corruption is difficult to deal with because: (1) it is often hidden, and thus hard to elucidate, (2) it has often been tacitly accepted as a means to an end or a way round inappropriate policies (Azfar et al., 2001), and (3) it is often ignored because of an understandable reluctance by both donors and recipients to highlight the issue. Donors risk losing credibility if their projects are considered unsuccessful, whilst recipients risk losing donor support if they are labelled as corrupt. Press freedom is often curtailed in corrupt countries, thereby further hindering scrutiny (Brunetti \& Weder, 2003).

Even where corruption can be identified, there is so little information that it can be difficult to know which solutions to apply. Anecdotal studies are important because they illustrate and publicize the role of corruption in conservation, but they are not sufficient to allow decision-makers to develop mitigation strategies. Instead, stories of poor governance tend to be used by advocates of different conservation paradigms to argue that corruption makes alternative systems untenable. Such debates are generally unhelpful because all of these paradigms rely on adequately working systems, and almost any system is open to subversion.

Consider, for example, the debate over wildlife trade bans. Proponents of trade bans argue that poor, corrupt countries are unable to regulate trade and find it more difficult to protect their threatened species when trade is allowed (Ginsberg, 2002). In contrast, opponents argue that trade bans can worsen the situation in corrupt countries if demand remains high, as they raise the value of the product and increase the power of corrupt officials, whilst doing nothing to improve species protection and law enforcement (Oldfield, 2002). Both sides of the argument are supported by committed and experienced conservationists, and both use the issue of corruption to question opposing views.

\section{Practical solutions in a world of imperfect information}

There is clearly a need for a more balanced evaluation that investigates both the vulnerability of different operational systems to corruption, and the efficacy and cost of potential corruption mitigation measures. However, most of the relevant (and relatively meagre) conservation literature simply describes the occurrence of the problem. Given the current lack of information, what should conservationists do?

One simplistic way of limiting the effects of corruption on donor projects could be to avoid working in countries with poor governance levels (Laurance, 2004) but this is problematic because many of these nations contain large numbers of endemic species and important habitats (Smith, Muir et al., 2003). Equally, with regard to international wildlife trade, it could be argued that the crippling power of poverty and corruption in originating countries mean that efforts should be directed towards reducing demand for wildlife products and increasing law enforcement to curb such trade in wealthier, less corrupt destination countries. However, there are reasons for thinking that just focusing on developed countries may not be effective. The first is that demand for wildlife is not restricted to these countries, as illustrated by the trade in rhino horn to Yemen and Asia (Martin et al., 1997; Mills, 1997). The second is that even well governed countries have been unsuccessful at stopping trade in illegal drugs and firearms (Oldfield, 2002), so it should not be assumed that they would be able to enforce wildlife trade bans effectively in the face of continued demand. Whilst it is sensible to base priority-setting exercises on governance and other socioeconomic data ( $\mathrm{O}^{\prime}$ Connor et al., 2003), it is almost inevitable that conservationists will have to work in corrupt countries.

However, recognizing and addressing the problem can yield successful conservation projects in even the most corrupt countries. If corruption is a rational response to an opportunity to maximize personal gain, then combating it involves changing the balance of payoffs to make the choice not to engage in corruption more appealing. This has been demonstrated in the water sector, where greater transparency to enable both internal and external monitoring and scrutiny served to increase the cost of misconduct (Davis, 2004). In conservation, some wellmanaged African protected areas have developed systems to ensure that different law enforcement teams 
scrutinize each other as a means of minimizing collusion in rhino poaching (Emslie \& Brooks, 1999). Equally, members of local communities can also provide important anti-poaching intelligence beyond park boundaries if they support relevant conservation initiatives (Walpole, 2004).

Transparency and accountability are logical solutions to corruption, and where they have been placed at the heart of conservation initiatives they have had a demonstrably positive effect, either by increasing donor confidence and the proper use of funds or improving benefit-sharing with communities (Child, 1995; Walpole \& Leader-Williams, 2001). Thus, instead of using corruption scores to blacklist countries, such data could be used to decide how projects are structured, supervised and audited so as to reduce problems. However, research on two Zambian community-based conservation programmes has shown that efforts to reduce such impacts can act as a significant drain on project budgets (Gibson, 1999), so care is needed when developing such mitigation methods.

\section{Enhancing research and understanding}

The lack of hard evidence on the role of corruption and the cost-effectiveness of measures to tackle it leads some to question whether corruption should be a focus for conservationists at all. Given the apparent interconnectedness of corruption, development, poverty and environment, it is difficult to disentangle the drivers from the symptoms. Currently it is not clear to what extent corruption plays a causal role in affecting conservation outcomes or, if proven, how significant that causal role may be. Equally, even if corruption does play an important causal role, the extent to which it should be prioritized over other known threats to biodiversity cannot currently be determined. Yet conservation actions that compete for limited funding, including those aimed at tackling corruption, should be justified and prioritized on the basis of good scientific evidence (Pullin \& Knight, 2001).

Like other donor-driven sectors, conservation can suffer from a disaster mentality, whereby continued declines are blamed on a lack of resources to combat increasing threats, rather than an inability to ensure productive use of funds and expertise (Haley \& Clayton, 2003). Whilst it is almost always true that the success of projects is limited by funding availability, conservationists are increasingly aware of the need to improve the effectiveness of these projects, both to improve biodiversity conservation and to convince donors that money will be well spent (Christensen, 2003). This requires a thorough understanding of the drivers of biodiversity decline and the effectiveness of interventions to combat them, which in turn requires further appropriate research; much of conservation action is still based on experience rather than evidence (Sutherland et al., 2004).

A full analysis must include social, economic and political drivers, including corruption, and the subject would benefit greatly from studies undertaken by interdisciplinary groups including conservationists, economists and political scientists. Other authors have described and developed frameworks to assist the conservation discipline to move towards evidence-based action (Pullin \& Knight, 2001; Salafsky et al., 2002). However, three areas where we believe attention could be fruitfully directed include: (1) identifying suitable measures of governance as it applies to conservation at local and national levels, (2) incorporating the measurement of change in governance indicators into rigorous monitoring and evaluation of project implementation and success, to determine the extent to which changes in governance affect conservation outcomes, and (3) scaling up to multi-site and cross-national comparisons of the impact of changing governance to identify common themes and transferable solutions.

\section{Conclusion}

In considering the ways that corruption may limit success in conservation, we hope to stimulate more transparent debate and analysis of this insidious problem. Whilst corruption is capable of affecting many aspects of conservation, this does not imply that its effects are universal and endemic. An acceptance of its existence is by no means an indication of its prevalence or an admission of guilt. Many conservation projects will be generally free of corruption and many conservationists will have evolved means of overcoming the problem where it does exist. Yet at the same time, whether recognized explicitly or not, many activities and initiatives will be constrained by corruption. However great or small its extent (an issue that we recognize is still unclear), corruption should not simply be ignored, and it is crucial that lessons learned in one location are made available elsewhere.

\section{Acknowledgements}

This essay benefited from insightful discussions with Clark Gibson, Paul Jepson, Peter Kareiva, Todd Katzner, Rob Muir, M. Sanjayan and Juan Carlos Vasquez. We are also grateful to Andrew Balmford, Jim Groombridge, Nigel Leader-Williams, Matt Linkie and three anonymous reviewers for commenting on an earlier draft. 


\section{References}

Archabald, K. \& Naughton-Treves, L. (2001) Tourism revenue-sharing around national parks in Western Uganda: early efforts to identify and reward local communities. Environmental Conservation, 28, 135-149.

Azfar, O., Lee, Y. \& Swamy, A. (2001) The causes and consequences of corruption. Annals of the American Academy of Political and Social Science, 573, 42-56.

Balmford, A. \& Whitten, T. (2003) Who should pay for tropical conservation, and how could the costs be met? Oryx, 37, 238-250.

Bardhan, P. (1997) Corruption and development: a review of issues. Journal of Economic Literature, 35, 1320-1346.

Barnes, R.F.W., Blom, A. \& Alers, M.P.T. (1995) A review of the status of forest elephants Loxodonta africana in Central Africa. Biological Conservation, 71, 125-132.

Barrett, C.B., Brandon, K., Gibson, C. \& Gjertsen, H. (2001) Conserving tropical biodiversity amid weak institutions. Bioscience, 51, 497-502.

Brunetti, A. \& Weder, B. (2003) A free press is bad news for corruption. Journal of Public Economics, 87, 1801-1824.

Campos, J.E., Lien, D. \& Pradhan, S. (1999) The impact of corruption on investment: predictability matters. World Development, 27, 1059-1067.

Child, G. (1995) Managing wildlife successfully in Zimbabwe. Oryx, 29, 171-177.

Christensen, J. (2003) Auditing conservation in an age of accountability. Conservation in Practice, 4, 12-19.

Damania, R., Fredriksson, P.G. \& List, J.A. (2003) Trade liberalization, corruption, and environmental policy formation: theory and evidence. Journal of Environmental Economics and Management, 46, 490-512.

Davis, J. (2004) Corruption in public service delivery: experience from South Asia's water and sanitation sector. World Development, 32, 53-71.

Doh, J.P., Rodriguez, P., Uhlenbruck, K., Collins, J. \& Eden, L. (2003) Coping with corruption in foreign markets. Academy of Management Executive, 17, 114-127.

Emslie, R. \& Brooks, M. (1999) African Rhino. Status Survey and Conservation Action Plan. IUCN/SSC African Rhino Specialist Group, Gland, Switzerland and Cambridge, UK.

Gibson, C.C. (1999) Politicians and Poachers: The Political Economy of Wildife Policy in Africa. Cambridge University Press, Cambridge, UK.

Ginsberg, J. (2002) CITES at 30, or 40. Conservation Biology, 16, 1184-1191.

Gupta, A. \& Siebert, U. (2004) Combatting forest corruption: the Forest Integrity Network. Journal of Sustainable Forestry, 19, 337-349.

Haley, M. \& Clayton, A. (2003) The role of NGOs in environmental policy failures in a developing country: the mismanagement of Jamaica's coral reefs. Environmental Values, 12, 29-54.

Huber, O. (2001) Conservation and environmental concerns in the Venezuelan Amazon. Biodiversity and Conservation, 10, 1627-1643.

Jepson, P., Jarvie, J.K., MacKinnon, K. \& Monk, K.A. (2001) The end for Indonesia's lowland forests? Science, 292, 859.

Johns, D.M. (2003) Growth, conservation, and the necessity of new alliances. Conservation Biology, 17, 1229-1237.

Kaufmann, D. (1997) Corruption: the facts. Foreign Policy, 107, 114-131.
Kiltgaard, R. (1998) International cooperation against corruption. Finance and Development, 35, 3-6.

Kinnaird, M.F., Sanderson, E.W., O’Brien, T.G., Wibisono, H.T. \& Woolmer, G. (2003) Deforestation trends in a tropical landscape and implications for endangered large mammals. Conservation Biology, 17, 245-257.

Lambsdorff, J.G. (2003) How corruption affects productivity. Kyklos, 56, 457-474.

Laurance, W.F. (2004) The perils of payoff: corruption as a threat to global biodiversity. Trends in Ecology E Evolution, 19,399-401.

Leader-Williams, N., Albon, S.D. \& Berry, P.S.M. (1990) Illegal exploitation of black rhinoceros and elephant populations patterns of decline, law-enforcement and patrol effort in Luangwa Valley, Zambia. Journal of Applied Ecology, 27, 1055-1087.

Leader-Williams, N. \& Milner-Gulland, E.J. (1993) Policies for the enforcement of wildlife laws - the balance between detection and penalties in Luangwa Valley, Zambia. Conservation Biology, 7, 611-617.

Martin, E.B. \& Vigne, L. (2003) Trade in rhino horn from eastern Africa to Yemen. Pachyderm, 34, 75-87.

Martin, E.B., Vigne, L. \& Allan, C. (1997) On a Knife's Edge: The Rhinoceros Horn Trade in Yemen. TRAFFIC International, Cambridge, UK.

Mauro, P. (1995) Corruption and growth. Quarterly Journal of Economics, 110, 681-712.

McCarthy, J.F. (2002) Turning in circles: district governance, illegal logging, and environmental decline in Sumatra, Indonesia. Society \& Natural Resources, 15, 867-886.

Mills, J.A. (1997) Rhinoceros Horn and Tiger Bone in China: An Investigation of Trade Since the 1993 Ban. TRAFFIC International, Cambridge, UK.

Myers, N. (1998) Lifting the veil on perverse subsidies. Nature, 392, 327-328.

Nishihara, T. (2003) Elephant poaching and ivory trafficking in African tropical forests with special reference to the Republic of Congo. Pachyderm, 34, 66-74.

O'Connor, C., Marvier, M. \& Kareiva, P. (2003) Biological vs social, economic and political priority-setting in conservation. Ecology Letters, 6, 706-711.

Oldfield, S. (2002) The Trade in Wildife: Regulation for Conservation. Earthscan, London, UK.

Palmer, C. (2001) The Extent and Causes of Illegal Logging: An Analysis of a Major Cause of Tropical Deforestation in Indonesia. CSERGE Working Paper, University College, London, UK.

Pullin, A.S. \& Knight, T.M. (2001) Effectiveness in conservation practice: pointers from medicine and public health. Conservation Biology, 15, 50-54.

Robertson, J.M.Y. \& van Schaik, C.P. (2001) Causal factors underlying the dramatic decline of the Sumatran orang-utan. Oryx, 35, 26-38.

Rock, M.T. \& Bonnett, H. (2004) The comparative politics of corruption: accounting for the East Asian paradox in empirical studies of corruption, growth and investment. World Development, 32, 999-1017.

Roe, D., Mayers, J., Grieg-Gran, M., Kothari, A., Fabricius, C. \& Hughes, R. (2000) Evaluating Eden: Exploring the Myths and Realities of Community-based Wildife Management: Series Overview. IIED, London, UK.

Rose-Ackerman, S. (1999) Corruption and Government: Causes, Consequences and Reform. Cambridge University Press, New York, USA. 
Sajo, A. (2003) From corruption to extortion: conceptualization of post-communist corruption. Crime Law and Social Change, 40, 171-194.

Salafsky, N., Margoluis, R., Redford, K.H. \& Robinson, J.G. (2002) Improving the practice of conservation: a conceptual framework and research agenda for conservation science. Conservation Biology, 16, 1469-1479.

Shleifer, A. \& Vishny, R.W. (1993) Corruption. Quarterly Journal of Economics, 108, 599-617.

Smith, J., Obidzinski, K., Subarudi \& Suramenggala, I. (2003) Illegal logging, collusive corruption and fragmented governments in Kalimantan, Indonesia. International Forestry Review, 5, 293-302.

Smith, R.J., Muir, R.D.J., Walpole, M.J., Balmford, A. \& Leader-Williams, N. (2003) Governance and the loss of biodiversity. Nature, 426, 67-70.

Sutherland, W.J., Pullin, A.S., Dolman, P.M. \& Knight, T.M. (2004) The need for evidence-based conservation. Trends in Ecology \& Evolution, 19, 305-308.

Thompson, M. \& Homewood, K. (2002) Entrepreneurs, elites, and exclusion in Maasailand: trends in wildlife conservation and pastoralist development. Human Ecology, 30, 107-138.

Transparency International (2002) Corruption Fighters' Tool Kit: Civil Society Experience and Emerging Strategies. Transparency International, Berlin, Germany.

Transparency International (2003) Annual Report 2003.

Transparency International, Berlin, Germany.

UN (2003) United Nations Convention against Corruption. Resolution 58/4 of 31 October 2003

[http://www.unodc.org/unodc/en/

crime_convention_corruption.html, accessed 15 February 2005].
Walpole, M.J. (2004) Community scouts promote conservation and livelihood security in the Mara Ecosystem, Kenya. Sustainable Development International, 10, 119-121.

Walpole, M.J. \& Leader-Williams, N. (2001) Masai Mara tourism reveals partnership benefits. Nature, 413, 771-771.

Wells, M., Guggenheim, S., Wardojo, W. \& Jepson, P. (1999) Investing in Biodiversity: A Review of Indonesia's Integrated Conservation and Development Projects. The World Bank, East Asia Region, Washington, DC, USA.

World Bank (2000) Helping Countries Combat Corruption: Progress at the World Bank since 1997. World Bank, Washington, DC, USA

WRI (2003) World Resources 2002-2004. World Resources Institute, Washington, DC, USA.

\section{Biographical sketches}

Bob Smith works on a conservation planning project that focuses on the Maputaland centre of endemism in Southern Africa. He is also interested in the role of positive incentives and economic systems in biodiversity conservation.

Matt Walpole was based at Durrell Institute of Conservation and Ecology for 10 years, where he specialized in multidisciplinary approaches to conservation, including humanwildlife conflict mitigation and the role of ecotourism as a conservation and development tool. He recently moved to Fauna \& Flora International where he is coordinating a global project exploring the links between livelihoods and conservation. 